\title{
O procedimento de colação sob uma perspectiva histórica: distinção entre as operações de computação, imputação e redução de liberalidades.
}

\author{
The procedure of attachment to the estate under a historical perspective: a distinction \\ between the operations of computation, imputation, and reduction of gifts.
}

Thalles Ricardo Alciati Valim *

\section{REFERÊNCIA}

VALIM, Thalles Ricardo Alciati. O procedimento de colação sob uma perspectiva histórica: distinção entre as operações de computação, imputação e redução de liberalidades. Revista da Faculdade de Direito da UFRGS, Porto Alegre, n. 47, p. 57-82, dez. 2021. DOI: https://doi.org/10.22456/0104-6594.108468.

\section{RESUMO}

$\mathrm{O}$ artigo propõe uma interpretação histórica das regras direta ou indiretamente relacionadas à colação, com o objetivo de se conciliarem as tradições provenientes do Direito Romano e do Direito germânico, amalgamadas no Direito Civil brasileiro, assegurando que a liberdade de testar não prejudique a proteção à legítima. Para isso, a análise toma por recorte temático as discussões acerca da natureza jurídica e dos efeitos da dispensa da colação.

\section{PALAVRAS-CHAVE}

Direito das Sucessões. Colação. Dispensa. Legítima.

\begin{abstract}
The article proposes a historical interpretation of the rules directly or indirectly related to the attachment to the estate, with the intent of conciliating the traditions that came from Roman Law and Germanic Law and were merged in Brazilian Private Law, assuring the freedom of disposition by will and at the same time protecting the compulsory share. To do so we focus on the analysis of the legal nature and the legal effects of the exclusion of the gift from the attachment to the estate by the donor.
\end{abstract}

\section{KEYWORDS}

Law of Succession. Attachment to the estate. Exclusion of gifts from attachment to the estate. Compulsory share.

\section{SUMÁRIO}

Introdução. 1. Direito Romano. 1.1. Collatio emancipati. 1.2. Collatio dotis. 1.3. Collatio donationes. 2. Direito Germânico. 3. Direito Espanhol antigo. 3.1. O Fuero de Cuenca. 3.2. As Sete Partidas. 3.3. As Leis do Toro. 4. As Ordenações do Reino de Portugal. 5. Código Civil de 1916. 6. Código Civil de 2002. Conclusões. Referências. Dados da publicação.

\footnotetext{
* Professor de Teoria Geral do Direito Civil e das Obrigações na Universidade do Estado de Minas Gerais (UEMG). Doutorando em Direito Civil pela Universidade de São Paulo (USP). Mestre em Direito Civil pela USP. Mestre em Droit et pratique des contrats pela Université Lumière - Lyon II. Bacharel em Direito pelas Universidades de São Paulo e Saint-Étienne (França).
} 


\section{INTRODUÇÃO}

A colação, tal como hoje é conhecida pelo direito posto, é resultado da amálgama de tradições diversas e da evolução dessas tradições com o passar do tempo. Por isso, para se compreender o regime atual, é preciso conhecer as origens de cada disposição e quais os fundamentos que levaram à orientação adotada pelo legislador brasileiro. Fundamentalmente, contrapõem-se dois modelos de colação, extraídos de tradições distintas.

De um lado, há o modelo proveniente do Direito Romano, que fundava o Direito das Sucessões sobre a liberdade quase irrestrita do testador. De outro, o do Direito Germânico, que em seus primórdios consagrava uma copropriedade familiar, calcada em uma espécie de solidariedade entre os membros da comunidade.

Nos países da Península Ibérica e em suas antigas colônias, a fusão dessas duas grandes tradições, a romana e a germânica, não foi feita sem que o contraste entre seus fundamentos fosse expurgado. Enquanto algumas regras claramente baseiam-se na liberdade de dispor romana, outras pretendem proteger certas classes de herdeiros contra a "tirania" da vontade do de cujus.

Frequentemente, a legislação e a doutrina confundem três operações diversas que, juntas, formam o procedimento de colação. A primeira delas, a computação, consiste em um cálculo matemático e contábil para a determinação da parte disponível, isto é, daquela parte que pode ser livremente disposta pelo autor da herança, em vida ou após o seu falecimento. A computação opera-se mediante a reunião de dois conjuntos de bens: (i) o donatum, isto é, tudo aquilo que foi doado pelo autor da herança aos herdeiros necessários, independentemente de ter havido dispensa de colação; (ii) e o relictum, que abrange todo o espólio do de cujus, subtraídas suas dívidas e outros encargos.

A computação das partes disponível e indisponível tem por fundamento legal o art. 1.847 do Código Civil, que dispõe: "Calcula-se a legítima sobre o valor dos bens existentes na abertura da sucessão, abatidas as dívidas e as despesas do funeral, adicionando-se, em seguida, o valor dos bens sujeitos a colação".

A segunda operação é chamada de imputação, pela qual os bens doados e os contidos no espólio são incluídos dentro das partes disponível ou indisponível. Sem que o autor da herança tenha feito destinação específica, os bens serão imputados na parte indisponível, razão pela qual, durante a imputação, essa porção da herança poderá ultrapassar o valor determinado durante a computação. 
O autor da herança pode afastar a presunção de destinação dos bens aos herdeiros necessários, no limite daquilo que foi determinado pela operação de computação. Ou seja, em um caso concreto, o de cujus poderá imputar bens, por doação ou disposição testamentária, na parte disponível, até o montante pela computação. Uma das formas de imputar um bem doado na parte disponível é mediante a dispensa de colação. Essa declaração de vontade do doador não afasta todas as operações da colação, como parece insinuar, mas apenas a presunção de que os bens doados a herdeiros necessários seriam antecipação de legítima. Mediante a dispensa de colação, portanto, o doador faz com que, durante a imputação, o bem doado a um herdeiro necessário possa ser imputado na parte disponível de sua herança.

O fundamento legal para a imputação das liberalidades na parte disponível da herança encontra-se no art. 2.005, segundo o qual: "São dispensadas da colação as doações que o doador determinar saiam da parte disponível, contanto que não a excedam, computado o seu valor ao tempo da doação".

Mas essa imputação do valor da doação dentro da parte disponível só será válida se, ao se somar às demais liberalidades feitas e às disposições de última vontade, não ultrapassar o limite estabelecido pela computação. Caso contrário, ter-se-á de dar início à terceira e última operação: a de redução das liberalidades.

A redução das liberalidades, por sua vez, é operação eventual dentro do procedimento de colação de liberalidades. Enquanto a computação e a imputação sempre ocorrem, a redução só deverá ser feita se alguma, ou algumas, das doações realizadas, ao serem imputadas na parte disponível da herança, descumprirem o limite estabelecido pela computação. Assim, prevê o art. 2.007 do Código Civil: "São sujeitas à redução as doações em que se apurar excesso quanto ao que o doador poderia dispor, no momento da liberalidade".

A confusão dessas três fases do procedimento de colação fez com que muitos autores brasileiros interpretassem a dispensa de colação de modo equivocado, como se houvesse uma permissão legal dirigida aos bens doados para que estes escapassem de qualquer verificação no momento da abertura da herança ${ }^{1}$. De acordo com essa interpretação, bastaria que a doação fosse, ao tempo em que realizada, de valor inferior a uma parte disponível fictícia ${ }^{2}$, entendida

\footnotetext{
${ }^{1}$ A título de exemplo: "Constituem objeto da colação, para a referida conferência, todas as doações feitas aos herdeiros necessários que não o tenham sido com dispensa de colação", cf. PENTEADO, Luciano de Camargo. Manual de Direito Civil: sucessões. São Paulo: Revista dos Tribunais, 2014, p. 242.

${ }^{2}$ A parte disponível ao momento da doação seria fictícia pois a verdadeira parte disponível só seria calculada no momento da abertura da sucessão.
} 
esta como a metade do patrimônio do doador no momento deste ato de liberalidade. Isso faria com que o esvaziamento patrimonial mediante doações sucessivas conseguisse escapar completamente do controle judicial a respeito de possível violação à legítima.

Ao se aceitar que o nosso direito sucessório emergiu de uma confluência de duas tradições jurídicas bastante distintas, torna-se forçoso concluir que uma análise histórica que busque retraçar geneticamente a origem das disposições relacionadas à colação das liberalidades presentes é essencial para a correta interpretação dessas normas jurídicas.

Para isso, o presente artigo parte da premissa de que a proteção da legítima é, ainda, um valor imanente no nosso sistema, pertencendo à ordem pública. Dessa forma, qualquer liberdade que seja reconhecida ao testador tem importância secundária, e apenas na medida em que não atenta contra aquele primeiro valor. Assim sendo, para que uma interpretação equivocada das regras sobre a colação não permita ao doador a subversão dessa ordem de valores, é preciso compreender que o procedimento da colação de liberalidades apresenta dentro de si três operações conexas, mas diversas, visto que baseadas em objetivos e fundamentos distintos.

A distinção dessas três etapas do procedimento de colação pode ser identificada nesse amálgama de tradições. Enquanto a computação privilegia a proteção da legítima, tendo raízes no Direito Germânico, a imputação busca assegurar ao testador a liberdade de dar o destino que deseja a seus bens na parte disponível, podendo ser identificada com a tradição romana. Para coibir abusos dessa segunda etapa e conciliar ambas as tradições do Direito lusófono, a redução das liberalidades restitui o equilíbrio entre as partes disponível e legítima, assegurando a proteção in concreto desta última.

\section{DIREITO ROMANO}

\subsection{COLLATIO EMANCIPATI}

A colação originou-se da atividade pretoriana, que permitiu o ingresso dos herdeiros emancipados na possessio bonorum, desde que fossem restituídos ao espólio os bens que teriam sido integrados ao patrimônio do paterfamilias caso a emancipação não tivesse 
ocorrido $^{3}$. Por isso, excluíam-se da colação os pecúlios castrense e quasi-castrense ${ }^{4}$. O objetivo da collatio bonorum era, no período clássico, permitir uma igualdade entre herdeiros emancipados e $s u i^{5}$. Constituía-se, destarte, em instrumento de equidade ${ }^{6}$. Foi introduzida, pelo menos, desde I d.C. (D. 37, 6, 2, 5). Era feita cautione e por stipulatio, quando o emancipado prometia dividir com os demais herdeiros os bens devidos, ou re, mediante a incorporação desses bens à massa hereditária ${ }^{7}$.

\subsection{COLLATIO DOTIS}

Paralelamente, surgiu a collatio dotis, permitindo à filha do paterfamilias o ingresso na possessio bonorum, desde que fossem trazidos à colação os dotes recebidos. A diferença principal entre a collatio dotis e a emancipati era a de que a primeira deveria ser feita independentemente de a filha ser ou não emancipada. Ainda, diferentemente da collatio emancipati, a colatio dotis tinha por objeto os bens doados pelo de cujus a título de dote ou em virtude de casamento. Havia, então, uma restrição a certas liberalidades feitas pelo de cujus, ao passo que a colação realizada pelos emancipados era referente a todos os bens que estariam contidos no patrimônio do paterfamilias caso os emancipados ainda estivessem sob o

\footnotetext{
${ }^{3}$ WINDSCHEID, Bernard. Diritto delle pandette. Tradução Carlo Fadda e Paolo Emilio Bensa. Torino: UTET, 1904, v. 3, p. 255.

${ }^{4}$ D. 37, 6, 1, 15 - "Não se leva à colação com os irmãos nem o pecúlio castrense, nem o quasi castrense; porque em muitas Constituições se reconhece que estes são exclusivos", cf. CORRAL, Ildefonso García del. Cuerpo del derecho civil romano: digesto. Barcelona: Jaime Molinas, 1897, t. 3, p. 31, tradução livre. No original: "Nec castrense nec quasi castrense peculium fratribus confertur: hoc enim praecipuum esse oportere multis constitutionibus continetur", cf. MOMMSEN, Theodor; KRÜGER, Paul. Corpus iuris civilis. 15. ed. Berlin: Weidmann, 1928, v. 1, p. 594.

${ }^{5}$ D. 37, 6, 1, 5 - "Assim, portanto, a colação ocorre sempre que, por intervenção de um emancipado, um filho não emancipado sofre algum prejuízo. Mas se este não sofrer, a colação não ocorrerá", cf. MOMMSEN, Theodor; KRÜGER, Paul. Corpus iuris civilis. 15. ed. Berlin: Weidmann, 1928, v. 1, p. 30, tradução livre. No original: "Totiens igitur collationi locus est, quotiens aliquo incommodo adfectus est is qui in potestate est interventu emancipati: ceterum si non est, collatio cessabit", cf. MOMMSEN, Theodor; KRÜGER, Paul. Corpus iuris civilis. 15. ed. Berlin: Weidmann, 1928, v. 1, p. 594.

${ }^{6}$ Ulpiano reconhece que o instituto é instrumento de equidade em passagem do Digesto. D. 37, 6, 1, pr. Ulpiano, nos Comentários ao Edito, livro XL — "Este título é de uma equidade manifesta, porque, como o Pretor admite aos emancipados a posse dos bens contra tabulas, e fá-los partícipes dos bens paternos juntamente com os filhos não emancipados, admite-se como consequência que aqueles que solicitam os bens paternos levem ao monte também os seus próprios", cf. CORRAL, Ildefonso García del. Cuerpo del derecho civil romano: digesto. Barcelona: Jaime Molinas, 1897, t. 3, p. 29, tradução livre. No original: "Ulpianus libro quadragesimo ad edictum pr. Hic titulus manifestam habet aequitatem: cum enim praetor ad bonorum possessionem contra tabulas emancipatos admittat participesque faciat cum his, qui sunt in potestate, bonorum paternorum: consequens esse credit, ut sua quoque bona in medium conferant, qui appetant paterna", cf. MOMMSEN, Theodor; KRÜGER, Paul. Corpus iuris civilis. 15. ed. Berlin: Weidmann, 1928, v. 1, p. 594.

${ }^{7}$ ALVES, José Carlos Moreira. Direito romano. 15. ed. Rio de Janeiro: Forense, 2012, p. 788.
} 
seu poder. Foi, portanto, através da collatio dotis que primeiro apareceu a finalidade de tratar igualmente todos os descentes ${ }^{8}$.

\subsection{COLLATIO DONATIONES}

As evoluções posteriores estenderam o dever de colacionar às hipóteses de recusa da herança (Antonino Pio) e de dote profectício (Gordiano ${ }^{9}$ ), alcançando a extensão máxima com Justiniano $^{10}$. Este imperador romano impôs a todos os descendentes o dever de colacionar o dote profectício, a doação propter nuptias e as doações para a obtenção de cargo público ${ }^{11}$. Com estas feições, a collatio foi denominada pela doutrina contemporânea collatio

\footnotetext{
${ }^{8}$ ALVES, José Carlos Moreira. Direito romano. 15. ed. Rio de Janeiro: Forense, 2012, p. 788; MOZOS, Jose Luis de los. La colación. Madrid: EDERSA, 1965, p. 20.

${ }^{9}$ C. 6, 20, 4. Imperador Gordiano, Augusto, a Marino - "As filhas são obrigadas a levar a colação o dote somente se sucederem ab intestato, ou se solicitarem a posse dos bens contra tabulas; e não se duvida que será preciso levar o dote, profectício ou adventício, dado ou constituído pelo pai, à colação em favor dos irmãos não emancipados. Ao passo que aqueles que não estão na família do defunto se determinou, após várias opiniões de jurisconsultos, que somente se leve à colação o dote profectício. Publicada em 4 de março de 239 d. C., por Gordiano, Augusto, e por Aviola", cf. CORRAL, Ildefonso García del. Cuerpo del derecho civil romano: código. Barcelona: Jaime Molinas, 1897, t. 5, p. 38, tradução livre. No original: "Imperator Gordianus . Filiae dotem in medium ita demum conferre coguntur, si vel ab intestato succedant vel contra tabulas petant: nec dubium est profecticiam seu adventiciam dotem a patre datam vel constitutam fratribus qui in potestate fuerunt conferendam esse. His etenim, qui in familia defuncti non sunt, profecticiam tantummodo dotem post varias prudentium opiniones conferri placuit * GORD. A. MARINO. *<A 239 PP. IIII ID. MART. GORDIANO A. ET AVIOLA CONSS.> "

${ }^{10}$ Nov. 18, 6- "Também acreditamos ser necessário tratar de outro assunto nesta Lei. Pois, querendo as anteriores leis, no que diz respeito às colações, que fossem feitas apenas quando morresse sem testamento o pai ou quando tivesse testado sem dizer nada acerca delas, não teria lugar a colação senão quando um (dos filhos) tivesse recebido as coisas doadas por dote ou por outra forma, e entrado em posse dos bens deixados (pelo falecido), dispomos que de modo algum possa prevalecer tal presunção. Quando alguém tiver falecido intestado, ou tendo testado, (porque não se sabe se por acaso se esqueceu do que doou, ou se próximo de sua morte não fez menção a esses bens), que tenha lugar em todos os casos a colação e a conseguinte igualdade, conforme ao que já antes era disposto, salvo se expressamente tiver indicado o falecido que não queria que fosse feita a colação. $\mathrm{O}$ obrigado à colação levará tanto aquilo que já foi recebido, quanto o que lhe será dado por testamento, mantendose em vigor tudo o que acerca das colações já tiver sido por nós anteriormente sancionado", cf. CORRAL, Ildefonso García del. Cuerpo del derecho civil romano: novelas. Barcelona: Jaime Molinas, 1898, t. 6, p. 97-98, tradução livre. No original: "Illud quoque bene habere credimus hac lege complecti. Prioribus enim legibus volentibus in collationibus, si quidem sine testamento morerentur parentes, collationes secundum earum virtutem fieri, si vero testati, nihil dicentes de eis, locum non fieri collationibus, sed et res habere per dotem forte aut alio modo datas et quae sunt relicta defendere: nos sancimus non esse omnino talem opinionem, sed sive quispiam intestatus moriatur seu testatus (quoniam incertum est, ne forsan oblitus datorum, aut pro tumultu mortis angustatus huius non est memoratus), omnino esse collationes et exinde aequalitatem, secundum quod olim dispositum est: nisi expressim designaverit ipse, velle non fieri collationem, sed habere eum, qui cogitur ex lege conferre, et quod iam datum est, et ex iure testamenti; omnibus, quae prius de collationibus a nobis sancita sunt, in sua virtute manentibus".

${ }^{11}$ ALVES, José Carlos Moreira. Direito romano. 15. ed. Rio de Janeiro: Forense, 2012, p. 789.
} 
descendentium. A transformação do instituto mostrou-se necessária, tendo em vista o desaparecimento da incapacidade dos filiifamilias $^{12}$.

Nesse estágio, no entanto, apenas essas liberalidades, chamadas de doações causais, eram colacionáveis. As doações simples, ou comuns, seriam colacionáveis somente quando o doador as tivesse expressamente exigido. Além disso, equiparando-se à collatio dotis, as liberalidades colacionáveis eram aquelas conferidas pelo paterfamilias quando da emancipação do herdeiro, e não tudo aquilo que teria sido incorporado ao patrimônio do paterfamilias caso não houvesse ocorrido a emancipação ${ }^{13}$. Assim, o instituto da colação foi sendo paulatinamente transformado mediante uma ampliação, tanto do rol de sujeitos (collatio descendentium) quanto de seu próprio objeto (collatio donationes) $)^{14}$.

Em virtude da ampla liberdade de testar reconhecida pelo Direito Romano, a colação representava, nesse período, a concretização de uma vontade presumida do autor da herança, que poderia ser afastada por declaração expressa em sentido contrário ${ }^{15}$. No entanto, essa transformação do instituto da colação no Direito Romano, transpondo-a para o campo sucessório com o objetivo de manter a igualdade entre herdeiros, veio a conflitar com outros institutos jurídicos diretamente ligados à proteção da legítima e oriundos de uma outra tradição jurídica: a germânica ${ }^{16}$.

\section{DIREITO GERMÂNICO}

A liberdade de testar não era conhecida no Direito Germânico, sistema em que a propriedade comum familiar influía de maneira decisiva ${ }^{17}$. A igualdade entre herdeiros era

\footnotetext{
${ }^{12}$ MOZOS, Jose Luis de los. La colación. Madrid: EDERSA, 1965, p. 22; WINDSCHEID, Bernard. Diritto delle pandette. Tradução Carlo Fadda e Paolo Emilio Bensa. Torino: UTET, 1904, v. 3, p. 257.

${ }^{13}$ MOZOS, Jose Luis de los. La colación. Madrid: EDERSA, 1965, p. 24.

${ }^{14}$ MOZOS, Jose Luis de los. La colación. Madrid: EDERSA, 1965, p. 22.

15 "Así en la collatio descendentium, hay que tener en cuenta que la relación con este campo jurídico, cuando el causante o testador quería mejorar a un hijo o descendiente, fuera de parte, acudía a una donación simple o a un prelegado; aparte de que no tenía necesidad de hacerlo, pues las facultades del testador eran muy amplias, y no surge esta necesidad de mejorar como en el Derecho posterior, consecuentemente con la falta de libertad o con su intensa restricción. De manera que el fundamento de la colación justinianea descansando en la voluntad presunta del causante (cuando dona anticipa)", cf. MOZOS, Jose Luis de los. La colación. Madrid: EDERSA, 1965, p. 9. No mesmo sentido: WINDSCHEID, Bernard. Diritto delle pandette. Tradução Carlo Fadda e Paolo Emilio Bensa. Torino: UTET, 1904, v. 3, p. 256.

${ }^{16}$ MOZOS, Jose Luis de los. La colación. Madrid: EDERSA, 1965, p. 29

${ }^{17}$ BRUNNER, Heinrich; SCHWERIN, Claudius von. Historia del derecho germánico. Tradução José Luis Álvarez López. Barcelona: Labor, 1936, p. 237.
} 
absoluta. A colação não poderia ser interpretada, tal como no Direito Romano, como instrumento de representação da vontade presumida do de cujus $^{18}$.

Embora os bens móveis pudessem ser apropriados a título particular, a propriedade imobiliária era pertencente a uma coletividade, em comum. Esse grupo de coproprietários poderia ser um clã, uma vila, uma aldeia ou o próprio núcleo familiar do falecido. Em termos jurídicos, essa visão coletiva da propriedade repercutiu nos ordenamentos influenciados pela tradição germânica mediante a imposição de impedimentos à alienação da propriedade familiar a terceiros. Os francos, por exemplo, impediam a alienação em vida da propriedade familiar, que deveria ser transmitida mortis causa aos filhos homens. Em casos excepcionais e limitados, a alienação era permitida, mas, ainda assim, a laudatio parentum impunha um direito de preferência, em benefício dos familiares, na aquisição do bem. Caso esse direito fosse desrespeitado, os familiares poderiam, no decorrer de um prazo determinado, reaver a propriedade das mãos do alienatário ${ }^{19}$.

Esse cenário fez com que o testamento entrasse em franco declínio, tendo praticamente desaparecido nas regiões ocupadas pelos povos germânicos durante a Alta Idade Média $^{20}$. As Leis Sálicas, por exemplo, não faziam qualquer referência ao testamento ${ }^{21}$. $\mathrm{O}$ ocaso das disposições de última vontade perdurou até, pelo menos, o século XII.

O ressurgimento das figuras testamentárias viria apenas com a recepção do Direito Romano, mas sem que a tensão entre as duas tradições desaparecesse. Houve, desde então, um conflito permanente entre essas duas funções, pertencentes a tradições diversas. De um lado, de acordo com a tradição romana, preocupava-se com a preservação da vontade presumida do autor da herança. De outro, a partir das raízes do Direito Germânico, procuravase restringir a liberdade de testar, com o objetivo de se protegerem os herdeiros legítimos ${ }^{22}$.

\footnotetext{
18 "La regla de la colación, pues, supone una aplicación particularizada de este equilíbrio, y de todo ello resulta una regulación de la institución diferente, respecto de su precedente en el antíguo Derecho castellano e, de los restantes Derechos romanistas", cf. MOZOS, Jose Luis de los. La colación. Madrid: EDERSA, 1965, p. 11.

${ }^{19}$ GILISSEN, John. Introdução histórica ao direito. Tradução A. M. Hespanha e L. M. Macaísta Malheiros. 2. ed. Lisona: Calouste Gulbenkian, 1995, p. 638.

${ }^{20}$ LÉVY, Jean-Philippe; CASTALDO, André. Histoire du droit privé. Paris: Dalloz, 2010, p. 1248.

${ }^{21}$ LÉVY, Jean-Philippe; CASTALDO, André. Histoire du droit privé. Paris: Dalloz, 2010, p. 1249.

${ }^{22}$ MOZOS, Jose Luis de los. La colación. Madrid: EDERSA, 1965, p. 10.
} 


\section{DIREITO ESPANHOL ANTIGO}

Na Idade Média, o território espanhol, assim como outras regiões, vivia uma situação de fragmentação e pluralismo normativo ${ }^{23}$. Essas duas características eram marcantes, sobretudo durante o período da Alta Idade Média. Em um primeiro grupo, continham-se as regiões influenciadas preponderantemente pelo Direito Romano, através da Lex Wisigothorum (Fuero Juzgo). Em outro, as regiões costumeiras, em que predominavam as decisões judiciais, chamadas Leis dos Foros. Dentre as Leis do Foro, a principal foi a do Fuero de Cuenca, editada provavelmente no reinado de Alfonso VIII, por volta de 1190. O Fuero de Cuenca teve grande influência nos foros de Castilla, Aragão e Portugal ${ }^{24}$. Vem daí a sua importância para o estudo das fontes portuguesas acerca da colação.

\subsection{O FUERO DE CUENCA}

Nas leis do Fuero de Cuenca, predominava a influência do Direito Germânico. Todos os herdeiros tinham o dever de colacionar, sem exceção ou possibilidade de dispensa pelo doador. O objetivo era estabelecer a igualdade absoluta entre os filhos ${ }^{25}$. Conforme salienta Vallet de Goytisolo, "durante esse período, a nossa legítima teve todas as características da reserva germânica mais pura" ${ }^{26}$. Assim, a redução operava de modo a estabelecer uma igualdade absoluta de quinhões ${ }^{27}$.

\footnotetext{
${ }^{23}$ GARCÍA, Carmen Muñoz. La colación como operación previa a la partición. Pamplona: Aranzadi, 1998, p. 25.

${ }^{24}$ GARCÍA, Carmen Muñoz. La colación como operación previa a la partición. Pamplona: Aranzadi, p. 26.

${ }^{25}$ GARCÍA, Carmen Muñoz. La colación como operación previa a la partición. Pamplona: Aranzadi, p. 27.

${ }^{26}$ VALLET DE GOYTISOLO, Juan. Apuntes de derecho sucesorio: posiciones y derechos de los legitimarios en el Código civil. Anuario de Derecho Civil, Madrid, fasc. 2, p. 421-532, 1951, p. 432, tradução livre.

${ }^{27}$ Fuero de Cuenca, Capítulo 10, $§ 22$ (Doações dadas pelo pai ou pela mãe a um filho ou uma filha no dia do seu casamento). "Quando os pais dão algo a seus filhos casados, tudo que eles deram deve ser sempre mantido, desde que os outros filhos possam ser recompensados do mesmo modo. Pois, quando a partilha for feita, estes têm direito quantitativamente igual aos bens que pertenciam aos seus pais falecidos. Se, no dia da partilha, aqueles que não receberam nada ainda não tiverem como ser recompensados, seus irmãos deverão trazer quantidade suficiente de bens de seus pais para que não haja excesso face aos demais irmãos, de modo que todos eles permaneçam em igual posição, após o pagamento de todas as dívidas, conforme já dito" Cf. ESPANHA (CUENCA). The Code of Cuenca: municipal law on the twelfth century castilian frontier. Tradução James F. Power. Philadelphia: University of Pennsylvania Press, 2000, p. 72-73, tradução livre, destacou-se.

${ }^{27}$ GARCÍA, Carmen Muñoz. La colación como operación previa a la partición. Pamplona: Aranzadi, 1998, p. 71-72, tradução livre, negritou-se.
} 
A proibição de preterição de um filho face a outro também se encontrava explícita no texto legal ${ }^{28}$ :

Fuero de Cuenca, Capítulo 10, § 27 (Os pais não podem doar a alguns de seus herdeiros mais do que a outros). Nós ordenamos, pelas razões acima elencadas, que nem o pai nem a mãe, saudáveis ou doentes, possam dar algo a mais a qualquer um de seus herdeiros, saudável ou doente. Pelo contrário, que cada um deles terá direito a receber em porções iguais, tanto a propriedade móvel quanto a imóvel.

\subsection{AS SETE PARTIDAS}

Um parcial rompimento com o pluralismo jurídico da Idade Média deu-se por uma iniciativa do rei Alfonso X, de Léon e Castilha, ao editar as Siete Partidas, inspiradas em diversas fontes, mas, principalmente, no Direito romano justinianeu ${ }^{29}$. As Siete Partidas tratavam da colação na Lei 3 do título IV da Partida 5 e nas Leis 3, 4, 5 e 6 do título XV da Partida 6:

Partida 6, Tít. XV, Lei 3 (Quais bens deve um irmão partilhar com os outros). Todas as coisas que o filho ganhar com os bens de seu pai, estando em seu poder, todas elas, deve ele trazer à colação com os outros bens que eram de seu pai, para partilhálas com os outros irmãos. Outrossim, dizemos que o dote, as arras ou a doação que o pai der em casamento a um de seus filhos deve ser imputada na parte daquele a quem foi dada, salvo quando o pai tiver dito expressamente, quando deu o bem ou em seu testamento, que não queria que ela fosse imputada nessa quota. E isso se dá quando os irmãos somente herdam os bens de seu pai ou de sua mãe. $(. . .)^{30}$.

No trecho acima citado, consolidou-se uma posição próxima à encontrada no Direito romano justinianeu. As doações propter nuptias e os dotes seriam colacionáveis, salvo dispensa expressa do doador, feita na própria doação ou por testamento. A obrigação de colacionar abrangia, ainda, tudo aquilo que havia sido adquirido pelo filho não emancipado com os bens recebidos de seu pai.

\footnotetext{
${ }^{28}$ ESPANHA (CUENCA). The Code of Cuenca: municipal law on the twelfth century castilian frontier. Tradução James F. Power. Philadelphia: University of Pennsylvania Press, 2000, p. 72-73, tradução livre.

${ }^{29}$ GARCÍA, Carmen Muñoz. La colación como operación previa a la partición. Pamplona: Aranzadi, 1998, p. 28.

${ }^{30}$ Partida 6, Tit. XV, Lei 3 (Quales ganancias es tenudo el un hermano de partir con el otro): "Todas la cosas que el fijo ganare en mercaderia con el auer de su padre seyendo en su poder, todas las deue aduzir a particion con los otros bienes que fueron de su padre, e partirlas con los otros hermanos. Otrosi dezimos, que la dote, o el arra, o la donacion, que el padre diere en casamiento a alguno de sus fijos, se deue contar en la parte de aquel a quien fue dada; fueras ende, si el padre dixesse señaladamente, quando gela daua, o en su testamento, que non queria que gela contassen en parte. E esto ha logar, quando los hermanos tan solamente heredan los bienes de su padre, o de su madre. (...)", cf. ESPANHA. Las Siete Partidas del Sabio Rey Don Alonso El Nono glosadas por el licenciado Gregorio Lopez. Madrid: Benito Cano, 1789, t. 3, p. 236-238, tradução livre.
} 
Assim como no Direito justinianeu, as doações simples eram distinguidas das doações causais. As doações simples não deveriam ser colacionadas e só se confirmariam com a morte do doador, podendo ele revogá-las até esse momento. As doações causais também não estariam, a princípio, sujeitas à colação, salvo se houvesse imposição do doador nesse sentido ou quando, diante de concorrência entre descendentes, fossem necessárias para se manter a igualdade entre eles. Surgia, então, a primeira referência à redução das liberalidades, na parte final da Partida 6, Tit. XV, Lei 4:

Partida 6, Tít. XV, Lei 4 (Quando as doações que o pai faz em sua vida a algum filho seu devem ser imputadas em sua quota ou não). Quando, em vida, o pai fizer doação a filho seu que estiver em seu poder, esse filho terá direito à doação feita, livre e firme, e ela não pode ser imputada em sua quota pelos outros irmãos no momento da partilha se não tiver sido revogada pelo pai até sua morte. Isso tudo é verdade, salvo quando o pai tiver dado em casamento aos irmãos algo, segundo dito por lei anterior a esta, e os demais filhos quiserem imputar em suas respectivas quotas os bens dados aos demais irmãos em virtude de casamento. Nesse caso, que seja imputada em sua quota igualmente a doação que o pai lhes fez em vida. E isso para que se guarde a igualdade entre os irmãos. Mas, se o pai tiver feito doação tão grande a um de seus filhos que os outros irmãos não puderam ter sua quota legítima com aquilo que restou dos bens do pai, então dizemos que devem reduzir tanto da doação feita até que possa ser entregue aos irmãos a parte legítima que devem receber ${ }^{31}$.

\subsection{AS LEIS DO TORO}

As Leis do Toro, editadas em 1505, também seguiram a tradição romana quanto à colação. A junção da preservação da legítima, com forte inspiração germânica, à liberdade de testar e de influir na imputação das liberalidades, causou a confusão entre as três fases da colação.

A Lei 25 contribuiu, em grande medida, para a confusão entre os institutos da computação e da imputação, ao dizer que "O terço e o quinto de melhora destinados pelo

\footnotetext{
${ }^{31}$ Partida 6, Tit. XV, Lei 4 (Como las donaciones que el padre faze en su vida a algund su fijo, si deuen ser contadas en su parte, o non): "En su vida faziendo donacion el padre a su fijo que estuuiesse en su poder, si despues non la reuocare fasta su muerte, este fijo aura la donacion que desta guisa le fuere fecha, libre e quita: e non gela pueden contar en su parte los otros hermanos en la particion, fueras ende, si el padre ouiesse dado en casamento a los hermanos alguna cosa, segund dize en la ley ante desta. Ca, si este fijo atal quisiesse contar a los otros hermanos en sus partes, las donaciones que el padre les fiziera en razon de casamiento; entonces dezimos, que sea otrosi contada en su parte la donacion que el padre fizo a el en su vida. E esto es, porque se guarde egualdad entre ellos. Pero si el padre fiziesse tan grand donacion al vno de sus fijos, que los otros sus hermanos non pudiessen auer la su parte legitima, en lo al que fincasse; dezimos, que estonce deuen menguar tanto de la donacion, fasta que puedan ser entregados los hermanos de la su parte legitima que deuen auer", cf. ESPANHA. Las Siete Partidas del Sabio Rey Don Alonso El Nono glosadas por el licenciado Gregorio Lopez. Madrid: Benito Cano, 1789, t. 3, p. 238-239, tradução livre, destacou-se.
} 
testador não podem ser retirados dos dotes e doações propter nuptias, nem das outras doações que os filhos ou descendentes trouxeram à colação e partilha"32.

Da leitura dessa lei, alguns autores entenderam que, para o cálculo da parte disponível, não se considerariam as doações dispensadas da colação ${ }^{33}$. No entanto, a maioria dos autores espanhóis considerou essa interpretação equivocada. Segundo estes últimos, a Lei 25 queria apenas dizer que, salvo disposição em contrário do testador, essas doações seriam imputadas na parte legítima. Não se trataria, portanto, de cálculo da parte disponível a ser respeitada pelo autor da herança, que cabe à computação, mas de imputação das liberalidades nas partes indisponível ou disponível ${ }^{34}$.

$\mathrm{Ou}$ seja, para se verificarem os valores a serem respeitados, tanto da parte disponível quanto da indisponível, todas as liberalidades deveriam ser trazidas à colação no momento da computação, pouco importando ter havido, ou não, dispensa. Entretanto, salvo expressa declaração do doador em contrário, os bens doados, mesmo aqueles por causa de casamento, não seriam imputados na parte disponível, que à época compunha-se dos chamados "terço e quinto de melhora". Era apenas isso que a Lei 25 do Toro, de modo um tanto quanto atravessado, buscava deixar claro.

De outro lado, a confusão entre redução e computação também se fazia presente. A Lei 29 do Toro iniciava mencionando a obrigação de colacionar, mas passava em seguida a falar do problema da redução das doações inoficiosas ${ }^{35}$. Essa inclusão de institutos diversos

\footnotetext{
${ }^{32}$ LLAMAS Y MOLINA, Don Sancho. Comentario critico, juridico, literal a las ochenta y tres leyes de Toro. 3 ed. anotada por Don José Vicente y Caravantes. Madrid: Gaspar y Reig, 1853, t. 1, p. 441, tradução livre.

${ }^{33}$ GARCÍA, Carmen Muñoz. La colación como operación previa a la partición. Pamplona: Aranzadi, 1998, p. 30.

${ }^{34}$ VALLET DE GOYTISOLO, Juan. Apuntes de derecho sucessório III: atribución de la legitima por actos intervivos. Anuario de Derecho Civil, Madrid, fasc. 4, p. 1031-1117, 1954, p. 1044; GARCÍA, Carmen Muñoz. La colación como operación previa a la partición. Pamplona: Aranzadi, 1998, p. 30.

35 "Quando algum filho ou filha herdar e partilhar bens de seu pai ou de sua mãe, ou de seus ascendentes, obrigam-se, eles e seus herdeiros, a trazer à colação e partilha o dote e a doação propter nuptias e as outras doações que tiverem recebido de seus pais cujos bens vem a herdar. Mas, se quiserem ficar fora da partilha, podem fazê-lo, salvo se o dote ou doações forem inoficiosos, pois nesse caso aqueles que os receberam serão obrigados a colacionar, assim como os filhos e os descendentes, em tudo quanto toca à doação, igualmente as filhas e seus maridos no que toca aos dotes aquilo que seja inoficioso para que partilhem entre si os outros herdeiros. E para dizer se tal dote é inoficioso, deve ser considerado aquilo que excede sua legítima, o terço e o quinto de melhora, no momento em que o doador podia fazer a dita melhora quando fez a doação, ou deu o dito dote, levando em consideração o valor dos bens do doador ou promitente ao tempo em que o dote foi constituído, ou prometido, ou a tempo da morte do doador ou promitente, podendo o donatário escolher entre um e outro momento. Mas, quanto às outras doações feitas aos filhos, para que se possa dizer se são inoficiosas, deve ser considerado o valor dos bens do doador ao tempo de sua morte". Cf. LLAMAS Y MOLINA, Don Sancho. Comentario critico, juridico, literal a las ochenta y tres leyes de Toro. 3 ed. anotada por Don José Vicente y Caravantes. Madrid: Gaspar y Reig, 1853, t. 1, p. 520, tradução livre, destacou-se.
} 
em um único dispositivo legal é a fonte apontada pelos autores espanhóis para a confusão entre as operações de imputação, redução e computação das liberalidades ${ }^{36}$.

Além disso, a Lei 29 tratava de um caso específico de imputação das doações ou dotes, qual seja, a hipótese em que um herdeiro-donatário tivesse recusado a herança. Nesse caso, as liberalidades recebidas só seriam reduzidas se fossem inoficiosas. Quando a doação tivesse sido feita propter nuptias, o donatário poderia escolher entre o momento em que se deu a liberalidade ou o da morte do doador para a avaliação do bem recebido. Nas demais liberalidades, não haveria escolha, sendo os valores da legítima, do quinto e da melhora, calculados quando da morte do doador. Ver-se-á, adiante, que a Lei 29 serviu de inspiração para as Ordenações Manuelinas (4, 77, 4) e Filipinas (4, 97, 4), que também estabeleceram esse duplo critério para o momento do cálculo da parte disponível.

\section{AS ORDENAÇÕES DO REINO DE PORTUGAL}

A Lei 29 do Toro, fonte de confusões no Reino da Espanha, acabou servindo de inspiração para o disposto acerca da colação nas Ordenações Manuelinas $(4,77,4)$ e Filipinas $(4,82,97,3)^{37}$. Apesar disso, as Ordenações Manuelinas continham menos equívocos na regulação da colação. De início, o título que compreendia as questões de colação, redução e imputação das doações não era intitulado "Das colações", como o seu equivalente nas Ordenações Filipinas. Desse modo, deixava-se mais claro que nem toda matéria ali contida tinha por objeto a colação em sentido estrito. Aliás, o primeiro parágrafo $(4,77$, pr.) tratava da ordem de vocação hereditária. A colação somente viria a aparecer no segundo parágrafo (4, $77,1)^{38}$.

\footnotetext{
${ }^{36}$ GARCÍA, Carmen Muñoz. La colación como operación previa a la partición. Pamplona: Aranzadi, 1998, p. 29

37 ROCHA, Manuel Antonio Coelho da. Instituições de direito civil portuguez. Coimbra: Imprensa da Universidade, 1852, t. 1, p. 242.

38 "E se o padre ou madre, ou ambos conjuntamente derem algua cousa mouel ou de raiz a alguu de seus filhos, quer em casamento, quer em qualquer outra maneira, será theudo tornar todo á partiçam aos outros seus irmaos, despois da morte do padre e madre que lhe a dita doaçam fezeram, com as nouidades que os ditos bens, que assi teuer em seu poder, e trouuer a colaçam, renderem despois da morte do padre ou madre atee o tempo das partilhas; porque nam os tendo em seu poder ao tempo que se o dito padre ou madre finar, nom será obriguado trazer as ditas nouidades aa colaçam; e esto, posto que polos irmaos lhe nom seja requerido, se elle entendendo que he seu proueito quiser com elles entrar aa herança; e bem assi trazerá aa colaçam tudo o que o dito filho ouuer de seu padre, ou madre, ou o que delles processe, que se chama em Dereito profectitio segundo diremos no Titulo seguinte", cf. PORTUGAL. Ordenações do Senhor Rey D. Manuel. Coimbra: Real Imprensa da Universidade, 1797, v. 4, p. 200-201, destacou-se.
} 
Vale a pena notar que o marco temporal para o valor dos bens sujeitos à colação era o da abertura da partilha. No entanto, o parágrafo 4 do mesmo título, seguindo a inspiração da Lei 29 do Toro, confundia os institutos da colação e da redução das liberalidades, apresentando em sua parte final a questão da inoficiosidade das doações feitas e adotando como marco temporal o duplo critério acima já observado nas Leis do Toro: (i) para as doações propter nuptias, a redução observaria o momento da doação ou da morte do doador; e (ii), para as demais doações, o da morte do doador ${ }^{39}$.

Essa passagem é replicada, com redação muito próxima, nas Ordenações Filipinas, tendo sido repartida em dois parágrafos $(4,97,3 ; 4,97,4)^{40-41}$. No segundo parágrafo decorrente dessa repartição, consagrou-se o duplo momento para a verificação da parte

39 "E se o filho ou filha, a que foi feita a doaçam por o padre ou madre, ou por ambos, assi em casamento como por qualquier outra maneira, nom quiser por morte do padre ou madre, ou d'ambos, entrar com os irmaos á herança do padre ou madre, ou d'ambos, nom será theudo tornar a seu irmao ou irmaos a cousa que lhe assi foi dada; saluo se essa doaçam for tam grande, e de tanta contia que trespasse, e exceda a legitima desse filho ou filha, a que foi feita a dita doaçam, e mais a terça da herança de seu padre ou madre, ou d'ambos, se ambos lhe a doaçam fezeram, por cuja causa a legitima do outro filho ou filhos fique em algua parte demenuida; porque em tal caso será esse filho, a que a doaçam foi feita, se a herança nom quiser entrar, obriguado a refazer ao irmao ou irmaos toda sua legitima, que dos bens do padre ou madre, ou d'ambos, se ambos a doaçam fezeram, tirada a terça lhe pertencer auer; e se elle ainda nom for entregue dos bens, ou quantidade de que lhe foi feita doaçam, nom poderá demandar, nem auer mais que o que montar em sua legitima, e na terça do pay, ou mãy, que lhe a tal doaçam fezeram; porque sempre as terças do padre e madre sam obriguadas a refazer os casamentos que prometem, e doaçoes que fazem a seus filhos atee onde abrangerem as ditas terças, posto que os defunctos dellas ordenem outra cousa, e ainda que expressamente nom fossem obrigadas E Declaramos, que pera se dizer que a dita doaçam he grande, e trespassa a legitima e a terça; se ha de oulhar a valia dos bens do que deu, ou prometeo os ditos bens em casamento, ao tempo que assi foram dados ou prometidos, ou ao tempo da morte do que deu, ou prometeo os ditos bens em casamento, qual mais quiser escolher aquelle, ou aquella, a quem foram dados ou prometidos os ditos bens em casamento, e esta escolha soomente será nas doaçoes que se fezerem aos filhos ou filhas, que nom forem pera casamento, se oulhará o que os bens do doador valerem ao tempo da sua morte". Cf. PORTUGAL. Ordenações do Senhor Rey D. Manuel. Coimbra: Real Imprensa da Universidade, 1797, v. 4, p. 202-203, destacou-se.

${ }^{40}$ Ord. Fil. 4, 97, 3: "E se o filho, ou filha, a que ambos, assi em casamento, como per qualquer outra maneira, não quizer por morte do pai, ou mãi, ou de ambos entrar com os irmãos à herança de pai, ou mãi, ou de ambos, não será obrigado tornar a seus irmãos a cousa, que lhe foi dada, salvo se a doação fôr tão grande, que exceda a legitima desse filho, ou filha, a que foi feita, e mais a terça da herança de seu pai, ou mãi, ou de ambos, se ambos lhe fizeram a doação, por cuja causa a legitima dos outros filhos fique em alguma parte diminuída; porque em tal caso, se à herança não quizer entrar, será obrigado a refazer aos irmãos toda sua legitima, que tirada a terça lhes pertence haver dos bens dos pai, ou mãi, ou de ambos, se ambos fizeram a doação. / E se elle ainda não for entregue dos bens ou quantidade, de que lhe foi feita doação, não poderá demandar, nem haver mais que o que montar em sua legitima, e na terça do pai, ou mai, que lhe fizeram tal doação. / Porque sempre as terias do pai, e mãi, até onde abrangerem, são obrigadas a refazer os casamentos, que promettem, e doações, que fazem a seus filhos, ainda que expressamente não fossem obrigadas, e postoque os defunctos dellas ordenem outra cousa", cf. PORTUGAL. Código Philippino ou Ordenações e Leis do Reino de Portugal. 14. ed. anotada por Candido Mendes de Almeida. Rio de Janeiro: Instituto Philomathico, 1870, t. 4, p. 972.

${ }^{41}$ Ord. Fil. 4, 97, 4: "E declarámos que para se dizer que a doação he grande, e excede a legitima e terça, se ha de olhar a valia dos bens do que os deu, ou prometteo em casamento ao tempo, que a fez, ou ao tempo de sua morte, qual escolher o donatario. E esta escolha será sómente nas doações dadas em casamento: porque nas outras doações, que se fizerem aos filhos, se olhará o que os bens do doador valerem ao tempo de sua morte", cf. PORTUGAL. Código Philippino ou Ordenações e Leis do Reino de Portugal. 14. ed. anotada por Candido Mendes de Almeida. Rio de Janeiro: Instituto Philomathico, 1870, t. 4, p. 973. 
disponível. Entretanto, a segmentação pode ter gerado ainda mais confusão, já que não se deixava claro que a regra era aplicável apenas à hipótese de renúncia à herança. Essa disposição foi, inclusive, objeto de comentário de diversos autores no século XIX. Sobretudo em decorrência da parte final do dispositivo, que, assim como a Lei 29 do Toro, permitia que a parte disponível fosse calculada no momento da liberalidade quando a doação fosse propter nuptias.

A doutrina da época buscou elucidar as confusões causadas pelo dispositivo. Teixeira de Freitas salientava que esse fragmento não tinha por objeto "collação verdadeira" ${ }^{42}$. De fato, era referente à redução das doações inoficiosas e à fixação do momento para o cálculo da parte disponível a ser tomada como referência. Coelho da Rocha ${ }^{43}$ e Correa Telles preocupavam-se com uma interpretação que pudesse prejudicar os demais herdeiros em hipótese de empobrecimento superveniente do doador, já que a parte disponível poderia ser calculada no momento da liberalidade. Por isso, Correa Telles ${ }^{44}$ advertia que esse parágrafo não poderia ser interpretado fora do contexto das Ordenações e que, caso houvesse empobrecimento do doador, a doação, ainda que não colacionável por renúncia à herança, deveria ser reduzida de modo a se satisfazerem os quinhões legítimos dos demais herdeiros. Na obra Digesto Portuguez, o autor citado formula proposta de regra expressa nesse sentido, baseando-se no Código da Prússia ${ }^{45}$.

Comentando o trecho citado das Ordenações Filipinas, Manuel de Almeida e Sousa de Lobão afirmava ser comum a confusão, pelos autores do século XVIII, entre os institutos da imputação e da colação ${ }^{46}$. Lobão alertava contra uma interpretação indevida, feita com

\footnotetext{
${ }^{42}$ TEIXEIRA DE FREITAS, Augusto. Consolidação das leis civis. ed. fac.-sim. Brasilia: Senado Federal, 2003, v. 2 , p. 693, nota 8.

${ }^{43}$ ROCHA, Manuel Antonio Coelho da. Instituições de direito civil portuguez. Coimbra: Imprensa da Universidade, 1852 , t. 1, p. 243.

${ }^{44}$ TELLES, José Homem Corrêa. Theoria da interpretação das leis e ensaio sobre a natureza do censo consignativo. Lisboa: Typographia Lacerdina, 1815, p. 27-28.

45 “ 1668 . Escolhendo o filho ou filha dotada o tempo do dote, tempo em que o doador era opulento, e o dote não excedia a terça, e legitima do dotado; se no tempo da morte tiver fallido, e não tiver com que preencha legitimas iguaes aos filhos indotados, recáe sobre o filho ou filhos dotados a obrigação que tinha o pai ou mãi de o alimentar, e de dotar os indotados", cf. TELLES, José Homem Corrêa. Digesto Portuguez. Pernambuco: M. F. de Faria, 1839, t. 3, p. 269.

${ }^{46} \mathrm{O}$ Autor estabelece uma distinção que também não é de todo correta, ao denominar imputação o que, na verdade, é operação de redução das doações: "Que a imputação só tem propriedade, quando um pae, testando, não deixa a um filho a sua inteira legitima. Este, n'esse caso, para se evitar a querela Inofficiosi ou a acção do supplemento da legitima, imputa e deve imputar o que por qualquer doação o pae lhe tivesse feito, os prelegados que lhe deixasse no testamento, etc.", cf. LOBÃO, Manuel de Almeida e Sousa de. Notas do uso prático e críticas, addições, illustrações e remissões à imitação das de Muller a Struvio sobre todos os títulos e todos os paragraphos do Livro Terceiro das Instituições do Direito Civil Lusitano do Dr. Paschoal José de Mello Freire. Lisboa: Imprensa Nacional, 1885, parte 3, p. 399.
} 
base no Direito Romano, dos dispositivos contidos nas Ordenações acerca da colação. Segundo ele, nesse assunto, o Direito Romano não foi a fonte empregada pelas Ordenações. As regras acerca da colação seriam:

originaes da nossa nação, conformes com os seus antigos e nacionaes costumes; que por elles só, e não pelo direito romano, se podem e devem interpretar. (...) Muito mais quando o direito romano, com vestígios do direito Quiritario, e da L. das doze tábuas, dava aos paes de familias aquella ampla faculdade de abandonar aos filhos $(4,2,3)$ que as nossas leis lhes restringem ${ }^{47-48}$.

Afastando-se da tradição romana e seguindo a portuguesa, Lobão afirmava não ser permitido ao pai escolher os bens que seriam imputados na parte disponível — na época, a terça - e justificava: “disponha o pae do terço geralmente como as leis lhe permittem; n'isto, usando da faculdade legal, a ninguem faz injuria; mas eleger bens certos, tomá-los em terço é abuso do poder, e escandalizar elle mesmo os mais filhos" ${ }^{" 49}$. Nesse ponto, Lobão lembrava da passagem presente nas Ordenações Filipinas, já aqui mencionada (4, 97, 3), mas descartava possível contradição com sua tese, pois ali não se trataria, propriamente, de imputação pelo de cujus de bens doados na parte disponível, mas de responsabilidade da terça pelas suas dívidas ${ }^{50}$.

\footnotetext{
${ }^{47}$ LOBÃO, Manuel de Almeida e Sousa de. Collecção de dissertações varias às quaes se fazem remissões no Tratado das Acções Summarias e Summarissimas. Lisboa: Imprensa Nacional, 1903, t. 2, p. 89.

${ }^{48} \mathrm{O}$ fundamento dessa imposição legal para a igualdade dos filhos seria: "Um pae deve mostrar amor igual a todos os filhos, para que não resulte o mau effeito que produziu a amorosa preferencia que Jacob tinha para José, Genes., C. 37, S. Ambros., sobre o Patriarc. José, C. 2, e L. 1, sobre Jacob, C. 2. E na disposição de seus bens deve observar toda a igualdade, prevenindo de futuro as emulações, os ódios e invejas dos filhos menos melhorados", cf. LOBÃO, Manuel de Almeida e Sousa de. Collecção de dissertações varias às quaes se fazem remissões no Tratado das Acções Summarias e Summarissimas. Lisboa: Imprensa Nacional, 1903, t. 2, p. 93.

${ }^{49}$ LOBÃO, Manuel de Almeida e Sousa de. Collecção de dissertações varias às quaes se fazem remissões no Tratado das Acções Summarias e Summarissimas. Lisboa: Imprensa Nacional, 1903, t. 2, p. 93.

50 "Nem o pae dispoz da terça, nem elegeu em terça bens alguns, nem tal foi a sua primeira intenção; esta foi unicamente dotar au doar certos bens ou quantidade debaixo de uma de duas intelligencias; ou de tornarem à collação os bens dotados e doados, e entrarem outra vez no cumulo da herança; ou de antecipar o pae o pagamento da legitima ao filho. (...) Como porém o dote ou doação, de que falla o dito $\S 3$ foi um contrato bilateral e obligatorio, como qualquer outra divida; por isso, abstendo-se o filho da herança, e excedendo os bens doados a sua legitima, disse a lei 'que sempre as terças do pae e mãe, até onde abrangerem, são obrigadas a refazer os casamentos que promettem, e doação que fazem a seus filhos, aindaque exressamente não fossem obrigadas'; bem como contrahindo o pae uma divida voluntaria, o pagamento por todos os seus bens vem a ser necessario, aindaque elle expressamente os não obrigasse; e aqui a terça fica dentro dos seus limites obrigada à satisfação da doação, para que não resulte inofficiosidade d'ella, que possam depois accusar os mais filhos, como suppõe o mesmo § 3", cf. LOBÃO, Manuel de Almeida e Sousa de. Collecção de dissertações varias às quaes se fazem remissões no Tratado das Acções Summarias e Summarissimas. Lisboa: Imprensa Nacional, 1903, t. 2, p. 95-96.
} 


\section{CÓDIGO CIVIL DE 1916}

O amálgama das tradições romana e germânica, representando o conflito entre a liberdade de testar e a proteção da legítima, atingiu seu ápice com o Código Civil de 1916. A dispensa à colação passa a ser prevista pelo legislador brasileiro em artigo específico, consagrando a colação nos moldes do Direito Romano, mesmo sem ter havido qualquer menção expressa a ela nas Ordenações do Reino. Ao mesmo tempo, a proteção à legítima pode ser sentida em todo o diploma legal, seja nas restrições estabelecidas para contratos onerosos celebrados entre ascendentes e descendentes (Código Civil de 1916, arts. 1.132 e 1.164, II), seja na inoficiosidade das doações (Código Civil de 1916, art. 1.176), seja ainda nas hipóteses de redução (Código Civil de 1916, art. 1.727) e rompimento do testamento (Código Civil de 1916, art. 1.750 e ss.).

A leitura dos dispositivos referentes à colação não pode, portanto, desconsiderar essa orientação que o legislador deu ao sistema, fruto de opção político-legislativa, em prol da legítima, doando-lhe força cogente. Por isso, sente-se o conflito entre a colação romana e a possibilidade de dispensa da colação pelo autor da herança, tal como adotada pelo ordenamento brasileiro.

Sob a vigência das Ordenações, além de não se ter tido texto expresso que permitisse a dispensa, os comentários dos autores do século XIX parecem ir em sentido contrário, negando essa possibilidade. Exemplificativamente, pode-se citar Lobão, que desenvolveu um estudo dedicado a provar a tese da impossibilidade de indicação, pelo testador, dos bens que seriam imputados na parte disponível. Como já visto, Lobão utilizava o argumento de que, nesse ponto, as Ordenações não se baseavam nas fontes romanas, mas no Direito lusitano antigo.

Já sob a égide do Código Civil de 1916, Astolpho de Rezende dizia ter dúvidas sobre a possibilidade de dispensa durante a vigência das Ordenações. No entanto, ponderava que, por ter sido o Direito Romano fonte supletiva nesse período, dever-se-ia concluir pela possibilidade de dispensa, mesmo sem norma expressa permissiva ${ }^{51}$.

Mas o argumento da força supletiva do Direito Romano não pode ser aceito sem reservas. Como visto, autores do século XIX, nomeadamente Lobão, advertiam contra a leitura, feita à luz do Direito romano, dos dispositivos acerca da colação. Nesse ponto, a

\footnotetext{
${ }^{51}$ REZENDE, Astolpho de. Manual do Código Civil brasileiro: do direito das successões. Rio de Janeiro: Jacintho Ribeiro dos Santos, 1930, v. 20, p. 384.
} 
tradição germânica teve influência igual, ou maior, a que a romana. Tudo indica, portanto, que não se conheceu a dispensa de colacionar as doações recebidas, nos moldes cunhados pelo Direito Romano, durante a vigência das Ordenações.

Diante dessa conclusão, pode-se inferir ter havido um rompimento no sistema sucessório brasileiro com a introdução, pelo Código Civil de 1916, da figura da dispensa de colação. Aderindo a uma parcela minoritária da doutrina do século XIX, que, a despeito das advertências de Lobão acerca da incompatibilidade com o sistema das Ordenações, supria a lacuna com as fontes romanas, Clóvis Beviláqua fez constar expressamente a possibilidade de dispensa de colação ${ }^{52}$.

Para tanto, o autor do hoje revogado Código Civil citava nota de Teixeira de Freitas a artigo da Consolidação das leis civis, em que o jurisconsulto do Império admitia a possibilidade de dispensa da colação. Ocorre que, no trecho citado, Teixeira de Freitas não chegava a admitir uma exclusão da colação pelo doador. Explicitando o dever de trazer as liberalidades à colação, Teixeira de Freitas ressalvava a possibilidade de o doador declarar algo em sentido contrário. E explicava como isso poderia ser feito: "isto é, que faz a doação por conta de sua terça, e não como anticipação de legitima, para que o donatario a-traga a collação. Eis o que exprime a declaração por parte do ascendente doador dispensado da collação ao descendente donatario" ${ }^{53}$.

Percebe-se, portanto, que Teixeira de Freitas não admitia uma dispensa "romana" de colação, mas simplesmente uma declaração emitida pelo doador para que o bem doado fosse imputado na parte disponível. Repitam-se as suas próprias palavras: "para que o donatario a-traga a collação".

Também era esse o entendimento de Pontes de Miranda. Ou seja, não se trataria propriamente de dispensa de colacionar, mas de permissão para imputar na parte disponível, desde que a liberalidade não ultrapassasse o limite verificado no cálculo de computação ${ }^{54}$ :

[n]as leis, fala-se de "dispensa de colação". Em verdade, não se dispensa a colação, não se pré-exclui o dever de colacionar. O que se permite é que se explicite ter-se posto na metade disponível aquilo que excede a quota do herdeiro necessário, ou que

\footnotetext{
${ }^{52}$ Em comentário ao art. 1.788 do Código Civil de 1916, Clóvis Beviláqua indicava que a dispensa da colação era reconhecida pela doutrina anterior com base no Direito romano. Cf. BEVILAQUA, Clóvis. Código Civil dos Estados Unidos do Brasil commentado. Rio de Janeiro: Francisco Alves, 1919, v. 6, p. 265.

53 TEIXEIRA DE FREITAS, Augusto. Consolidação das leis civis. ed. fac.-sim. Brasilia: Senado Federal, 2003, v. 2, p. 694-695, destacou-se.

${ }^{54}$ MIRANDA, Francisco Cavalcanti Pontes de. Tratado de Direito Privado: direito das sucessões. Atualizado por Giselda Hironaka e Paulo Lôbo. São Paulo: Revista dos Tribunais, 2012, t. 55, p. 353-354.
} 
lhe foi doado, ou dado em dote, em vida do decujo. Não há dispensa; há inclusão no quanto disponível do que teria de ser colacionado. (...) O que o decujo estabelece é só que se verifique se o valor que o herdeiro necessário recebera ou vai receber cabe na quota disponível e se considere livre de qualquer medida de igualização.

A confusão a respeito do que seria tecnicamente uma "dispensa de colação" levou a um problema hermenêutico em relação à parte final do art. 1.788. Este dispositivo afirmava, ipsis litteris: "São dispensados da colação os dotes ou as doações que o doador determinar que saiam de sua metade, contanto que não a excedam, computado o seu valor ao tempo da doação". Ora, ao se escolher o momento da doação para o cálculo de computação da parte disponível, permitia-se que o doador não só pudesse imputar o valor doado na parte disponível da herança, mas também escolher qual seria a própria extensão dessa parte. Isto porque, por um mecanismo de doações sucessivas, reduzir-se-ia o patrimônio e, por consequência, o próprio valor a ser respeitado como parte indisponível. Obviamente, um doador não poderia ter esse poder, haja vista a parte indisponível ser fixada para a proteção da legítima, instituto este de ordem pública.

A adoção do momento da liberalidade como marco temporal para o cálculo da computação da parte disponível da herança foi justificada por Beviláqua como sendo uma forma de superar a regra do duplo marco temporal, presente nas Ordenações, e que permitia ao donatário optar pelo momento da doação ou da morte do doador. Entretanto, como já se expôs, essa regra, presente tanto nas Ordenações Manuelinas quanto nas Filipinas, não dizia respeito à dispensa da doação, mas à hipótese de recusa de herança, pelo donatário, que deveria, ainda assim, reduzir as liberalidades recebidas quando ultrapassassem a parte disponível. A confusão foi fruto da segmentação, nas Ordenações Filipinas, do dispositivo em dois parágrafos.

Não bastasse a impropriedade de se utilizar critério pertinente apenas para o caso de renúncia da herança, esqueceu-se ainda que o duplo momento de avaliação da parte disponível tinha aplicação restrita aos dotes e doações propter nuptias, as chamadas doações causais no Direito Romano. Assim restrita, a possibilidade de escolha do momento de aferição da parte disponível fazia sentido, já que a colação das doações causais era originária do Direito Romano, em que vigorava uma ampla liberdade de testar. Nas demais doações, ditas simples, o mesmo fundamento não estava presente. Razão esta que parece ter motivado o compilador português a não conceder o mesmo benefício ao donatário. Fazendo tábula rasa dessa distinção, originalmente baseada em tradições diversas, Beviláqua estendeu regra 
excepcionalíssima à generalidade dos casos, introduzindo no ordenamento jurídico um dispositivo de difícil compatibilização com as demais regras sucessórias.

Não só isso, mas se criou norma inútil, pois incidia exatamente nos mesmos casos em que o art. 1.776, que cominava a sanção de nulidade para as doações "quanto à parte, que exceder a de que o doador, no momento da liberalidade, poderia dispor em testamento". Beviláqua reconheceu essa redundância, ao indicar que o art. 1.788 era simples "aplicação da regra estabelecida pelo art. $1.176^{, 55}$.

A confusão entre colação e computação também se deu na redação do art. 1.722, que estabelecia, em seu caput, o cálculo da parte disponível e, no parágrafo único, o da legítima. $\mathrm{O}$ artigo apresentava duas bases de cálculo distintas para as duas partes. Quanto à parte disponível, eram somados apenas o valor do relictum, isto é, dos "bens existentes ao falecer" com as dívidas e despesas de funeral. Por outro lado, a parte legítima era calculada sobre a metade do valor encontrado conforme o cálculo apresentado no caput, adicionando-se em seguida "a importância das doações por ele feitas aos seus descendentes (art. 1.785)."

Com isso, o Código Civil de 1916 divergia da maior parte das codificações da época, inclusive do Código de Portugal (Código Seabra) ${ }^{56}$. Para justificar esse rompimento com a tradição lusófona, Beviláqua argumentava que o cálculo apresentado já teria sido empregado pelos autores do século XIX, sob a vigência das Ordenações, ainda que estas não apresentassem regra expressa. A título de exemplo, Beviláqua citava os magistérios de Teixeira de Freitas e Coelho da Rocha. O problema, contudo, é que Teixeira de Freitas e Coelho da Rocha basearam-se em um estudo de Lobão que não tinha por objeto a computação das partes legítima e disponível, mas tão somente a possibilidade de indicação, pelo testador, dos bens que entrariam na parte disponível. Eram estudos que tratavam, portanto, de imputação das liberalidades, não de computação das partes disponível e indisponível.

Lobão citava resolução régia que se baseava, segundo ele, na Lei 25 do Toro ${ }^{57}$. Como já visto, a Lei 25 do Toro também foi fonte de confusão no Reino da Espanha, quando uma minoria de autores entendeu que o cálculo da parte disponível não incluiria as doações feitas pelo de cujus em vida. No entanto, esse entendimento logo foi superado pela maioria

\footnotetext{
${ }^{55}$ BEVILAQUA, Clóvis. Código Civil dos Estados Unidos do Brasil commentado. Rio de Janeiro: Francisco Alves, 1919, v. 6, p. 266.

${ }^{56}$ Beviláqua estava ciente desse rompimento, cf. BEVILAQUA, Clóvis. Código Civil dos Estados Unidos do Brasil commentado. Rio de Janeiro: Francisco Alves, 1919, v. 6, p. 172.

${ }^{57}$ LOBÃO, Manuel de Almeida e Sousa de. Collecção de dissertações varias às quaes se fazem remissões no Tratado das Acções Summarias e Summarissimas. Lisboa: Imprensa Nacional, 1903, t. 2, p. 101.
} 
dos intérpretes, que identificou na disposição apenas um preceito acerca da imputação das doações em uma das parcelas da herança deixada pelo de cujus. Diversa seria, no entanto, a questão com relação à computação da reserva para o cálculo da inoficiosidade das doações.

Como visto, a interpretação equivocada da Lei 25 do Toro influenciou os comentadores brasileiros e portugueses das Ordenações, que utilizaram um estudo de Lobão cuja posição estava, na verdade, em consonância com o que era entendido pela maioria dos autores espanhóis.

Ao se excluírem as liberalidades do cálculo da parte disponível feito pela computação, deixava-se o donatário a descoberto, caso tivesse havido empobrecimento do autor da herança, já que pouco ou nada restaria para o cálculo da parte disponível e a doação recebida seria, provavelmente, considerada inoficiosa. O problema não foi maior porque, seguindo Beviláqua, a maior parte dos autores do século XX interpretou a dispensa da colação nos moldes romanos, isto é, como verdadeira dispensa do valor doado de todo o procedimento de colação, em suas três etapas. A verificação de eventual inoficiosidade ocorreria apenas quando a liberalidade fosse feita, com base em uma parte disponível fictícia, hipotética e, por isso mesmo, variável no decorrer da vida do doador.

\section{CÓDIGO CIVIL DE 2002}

Parte das dificuldades hermenêuticas apresentadas pelo Código Civil de 1916 foi solucionada com a edição do Código Civil de 2002, sobretudo no que diz respeito à computação das partes disponível e legítima. Retomando a tradição lusitana antiga e o cálculo encontrado nos demais ordenamentos, o legislador brasileiro unificou a base de cálculo das duas partes com o art. 1.847 .

$\mathrm{Na}$ verdade, o dispositivo apresenta, de modo expresso, regra apenas para o cálculo da legítima. Contudo, ao revogar a antiga regra acerca da parte disponível, é razoável assumir que o cálculo, tanto para uma quanto para a outra parte, será o mesmo. Quisesse o legislador apresentar base diversa de cálculo para a parte disponível, teria seguido a formulação de Clóvis Beviláqua.

Portanto, a computação, com o art. 1.847, volta a se tornar independente da imputação. A base de cálculo para as partes legítima e disponível é a somatória do relictum e 
do donatum ${ }^{58}$. Com isso, a dispensa da colação pode voltar a fazer sentido no sistema apresentado pelo Código Civil brasileiro, pois, tratando-se de mera imputação na parte disponível, não permite a exclusão de certas liberalidades do seu cálculo, que deve ser feito no momento da abertura da sucessão, independentemente da vontade do autor da herança.

Não obstante isso, persiste, no Código atual, regra equivalente àquela do antigo art. 1.788. De acordo com o art. 2.005 do Código Civil de 2002:

[s]ão dispensadas da colação as doações que o doador determinar saiam da parte disponível, contanto que não a excedam, computado o seu valor ao tempo da doação.

Depreende-se do artigo citado que o momento para o cálculo da parte disponível permaneceria sendo aquele da doação. Se assim for interpretado o art. 2005 do Código Civil, as contradições com as demais normas, sobretudo aquelas de proteção à legítima, permanecerão. Além disso, a regra continuará sendo inútil, em virtude do art. 549, que já prevê a nulidade das doações que ultrapassem o que o doador poderia dispor "no momento da liberalidade". A redundância normativa aumentará, contudo, pois o art. 2.007 também repete o mesmo preceito, ao dispor serem "sujeitas à redução as doações em que se apurar excesso quanto ao que o doador poderia dispor, no momento da liberalidade".

\section{CONCLUSÃO}

A formação do Direito das Sucessões brasileiro deu-se, assim como em toda a civilística nacional, a partir de "galho de planta, que o colonizador português, - gente de rija têmpera, no ativo século XVI e naquele cansado século XVII em que se completa o descobrimento da América, - trouxe e enxertou no novo continente" ${ }^{\text {"59 }}$. E a planta da qual esse galho foi extraído bebeu em fontes de água diversas, tanto em origem quanto em substância.

De um lado, a tradição romana, de influência minoritária no Direito das Sucessões brasileiro, trouxe-nos a liberdade de testar e, nos limites que a lei a permite, a dispensa de colacionar certas liberalidades feitas em vida pelo de cujus. De outro, a tradição germânica,

\footnotetext{
${ }^{58}$ PEREIRA, Nelson Pinto. Da colação no direito civil brasileiro e no direito civil comparado. São Paulo: Juarez de Oliveira, 2002, p. 193.

${ }^{59}$ MIRANDA, Francisco Cavalcanti Pontes de. Fontes e evolução do direito civil brasileiro. 2. ed. Rio de Janeiro: Forense, 1981, p. 27.
} 
que cunhou grande parte das normas pertinentes ao direito sucessório e, com base nas ideias de propriedade familiar comunitária, moldou a legítima conferida aos herdeiros necessários.

Até o fim da vigência das Ordenações Filipinas em nosso país, não se conhecia uma verdadeira dispensa de colação, entendida esta como uma declaração unilateral de vontade do doador afastando do donatário o dever de reportar o valor recebido no momento da abertura da sucessão. Na prática, tal declaração de vontade, se possível, tornaria a liberalidade feita imune a variações patrimoniais posteriores. O posterior e sucessivo esvaziamento do patrimônio do de cujus poderia por em risco o equilíbrio mínimo que a lei buscava impor mediante a preservação da legítima.

Clóvis Beviláqua, baseando-se na visão romana que preconizava a liberdade de testar, deu interpretação diversa aos dispositivos das Ordenações Filipinas concernentes à colação. Com isso, importou do Direito romano elemento estranho ao Direito português antigo. A dispensa de colação, tal como imaginada por Beviláqua, jamais poderia ser reconhecida no ordenamento jurídico brasileiro enquanto o instituto da legítima estivesse vigente.

Para que as confusões sejam dissipadas, é preciso que a dispensa de colação seja compatibilizada com a preservação da legítima. E isso só pode ser feito recolocando-a em seu devido lugar, dentro de uma das etapas da colação: a imputação de liberalidades.

Quando um doador dispensar uma doação da colação, não a estará tornando imune ao procedimento como um todo. Muito pelo contrário. $\mathrm{O}$ valor recebido continua devendo ser comunicado no momento da abertura da sucessão. E isso se dá, pois, salvo nos casos em que o próprio legislador as afasta (e.g., Código Civil, arts. 2.010 e 2.011), as doações devem ser computadas para o cálculo dos limites a serem respeitados nas partes disponível e indisponível. Nesta etapa, conforme dispõe o art. 1.847, somam-se "os bens existentes na abertura da sucessão, abatidas as dívidas e as despesas do funeral, adicionando-se em seguida, o valor dos bens sujeitos a colação", ou seja, das liberalidades feitas pelo de cujus em vida, com ou sem dispensa de colação.

Apenas na etapa seguinte, é que as liberalidades serão imputadas em cada uma das partes da herança, de modo a verificar se a somatória obtida ultrapassa o valor estipulado na etapa anterior, da computação (Código Civil, 2.005). Caso ultrapasse, haverá a redução das liberalidades, limita ao "excesso quanto ao que o doador poderia dispor, no momento da liberalidade" (Código Civil, art. 2.006). 
Bem apartadas, as operações de computação, imputação e redução das liberalidades permitem solucionar não só o conflito entre a suposta "dispensa" de colação e a preservação da legítima, mas também aquele outro acerca do marco temporal a partir do qual será avaliado o bem doado, se no momento em que a doação foi feita ou a sucessão, aberta. Os dispositivos legais que fazem menção à avaliação do bem recebido quando da realização da doação dizem respeito à imputação e, portanto, só ocorrerão em etapa posterior à verificação do valor total a ser respeitado a título de parte legítima (computação). Nesta primeira etapa, todo e qualquer bem, seja ele presente no espólio, seja ele doado anteriormente, será avaliado tendo como marco temporal a morte do de cujus.

\section{REFERÊNCIAS}

ALVES, José Carlos Moreira. Direito romano. 15. ed. Rio de Janeiro: Forense, 2012.

BRUNNER, Heinrich; SCHWERIN, Claudius von. Historia del derecho germánico. Tradução José Luis Álvarez López. Barcelona: Labor, 1936.

CORRAL, Ildefonso García del. Cuerpo del derecho civil romano: digesto. Barcelona: Jaime Molinas, 1897, t. 3.

CORRAL, Ildefonso García del. Cuerpo del derecho civil romano: código. Barcelona: Jaime Molinas, 1897, t. 5.

CORRAL, Ildefonso García del. Cuerpo del derecho civil romano: novelas. Barcelona: Jaime Molinas, 1898, t. 6.

ESPANHA (CUENCA). The Code of Cuenca: municipal law on the twelfth century castilian frontier. Tradução James F. Power. Philadelphia: University of Pennsylvania Press, 2000.

ESPANHA. Las Siete Partidas del Sabio Rey Don Alonso El Nono glosadas por el licenciado Gregorio Lopez. Madrid: Benito Cano, 1789, t. 3.

GARCÍA, Carmen Muñoz. La colación como operación previa a la partición. Pamplona: Aranzadi, 1998.

GILISSEN, John. Introdução histórica ao direito. Tradução A. M. Hespanha e L. M. Macaísta Malheiros. 2. ed. Lisona: Calouste Gulbenkian, 1995.

LÉVY, Jean-Philippe; CASTALDO, André. Histoire du droit privé. Paris: Dalloz, 2010.

LLAMAS Y MOLINA, Don Sancho. Comentario critico, juridico, literal a las ochenta y tres leyes de Toro. 3 ed. anotada por Don José Vicente y Caravantes. Madrid: Gaspar y Reig, 1853, t. 1.

LOBÃO, Manuel de Almeida e Sousa de. Notas do uso prático e críticas, addições, illustrações e remissões à imitação das de Muller a Struvio sobre todos os títulos e todos os 
paragraphos do Livro Terceiro das Instituições do Direito Civil Lusitano do Dr. Paschoal José de Mello Freire. Lisboa: Imprensa Nacional, 1885, parte 3.

LOBÃO, Manuel de Almeida e Sousa de. Collecção de dissertações varias às quaes se fazem remissões no Tratado das Acções Summarias e Summarissimas. Lisboa: Imprensa Nacional, 1903 , t. 2.

MIRANDA, Francisco Cavalcanti Pontes de. Fontes e evolução do direito civil brasileiro. 2. ed. Rio de Janeiro: Forense, 1981.

MIRANDA, Francisco Cavalcanti Pontes de. Tratado de Direito Privado: direito das sucessões. Atualizado por Giselda Hironaka e Paulo Lôbo. São Paulo: Revista dos Tribunais, 2012 , t. 55.

MOMMSEN, Theodor; KRÜGER, Paul. Corpus iuris civilis. 15. ed. Berlin: Weidmann, 1928, v. 1.

MOZOS, Jose Luis de los. La colación. Madrid: EDERSA, 1965.

PENTEADO, Luciano de Camargo. Manual de Direito Civil: sucessões. São Paulo: Revista dos Tribunais, 2014.

PORTUGAL. Ordenações do Senhor Rey D. Manuel. Coimbra: Real Imprensa da Universidade, 1797, v. 4.

PORTUGAL. Código Philippino ou Ordenações e Leis do Reino de Portugal. 14. ed. anotada por Candido Mendes de Almeida. Rio de Janeiro: Instituto Philomathico, 1870, t. 4.

ROCHA, Manuel Antonio Coelho da. Instituições de direito civil portuguez. Coimbra: Imprensa da Universidade, 1852, t. 1.

TEIXEIRA DE FREITAS, Augusto. Consolidação das leis civis. ed. fac.-sim. Brasilia: Senado Federal, 2003, v. 2.

TELLES, José Homem Corrêa. Theoria da interpretação das leis e ensaio sobre a natureza do censo consignativo. Lisboa: Typographia Lacerdina, 1815.

TELLES, José Homem Corrêa. Digesto Portuguez. Pernambuco: M. F. de Faria, 1839, t. 3.

VALLET DE GOYTISOLO, Juan. Apuntes de derecho sucesorio: posiciones y derechos de los legitimarios en el Código civil. Anuario de Derecho Civil, Madrid, fasc. 2, p. 421-532, 1951.

VALLET DE GOYTISOLO, Juan. Apuntes de derecho sucessório III: atribución de la legitima por actos intervivos. Anuario de Derecho Civil, Madrid, fasc. 4, p. 1031-1117, 1954.

WINDSCHEID, Bernard. Diritto delle pandette. Tradução Carlo Fadda e Paolo Emilio Bensa. Torino: UTET, 1904, v. 3. 


\section{DADOS DA PUBLICAÇÃO}

Categoria: artigo submetido ao double-blind review.

Recebido em: 16/10/2020.

Aceito em: 30/11/2021. 